Open Journal System

Volume 1 no 12020

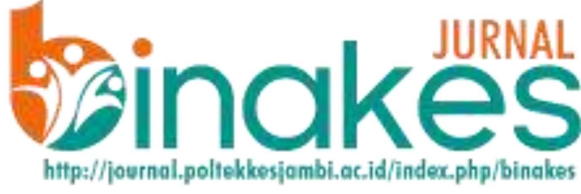

\title{
PEMBERDAYAAN KADER DALAM DETEKSI DINI KOMPLIKASI MASA NIFAS DI DESA PENYENGAT OLAK KEC. JAMBI LUAR KOTA KAB. MUARO JAMBI TAHUN 2019
}

Ika Murtiyarini ${ }^{1}$, Yuli Suryanti ${ }^{1}$, Ajeng Galuh Wuryandari ${ }^{1}$

${ }^{1}$ Jurusan Kebidanan Poltekkes Kemenkes Jambi

\section{KONTAK PENULIS}

ika.murtiyarini@gmail.com

DOI:

https://doi.org/10.35910/binake s.v1i1.371

Kata Kunci:

pemberdayaan kader; deteksi dini; masa nifas

\section{ABSTRAK}

Latar Belakang: Masalah kebidanan di masyarakat merupakan masalah yang kompleks dan perlu mendapat perhatian. Kader kesehatan merupakan sasaran yang tepat dalam pelaksanaan program kesehatan karena dianggap sebagai tempat rujukan pertama pelayanan kesehatan. Kader kesehatan dilatih dan berfungsi sebagai monitor, pengingat dan pendukung untuk mempromosikan kesehatan.

Metode: Peningkatan pengetahuan kader dilakukan melalui penyuluhan dengan memberikan buku saku pada sasaran sebanyak 30 orang. Pengetahuan diukur menggunakan kuesioner. Pengabdian kepada masyarakat ini dilaksanakan di Desa Penyengat Olak Kec. Jambi Luar Kota Kab. Muaro Jambi.

Hasil: Terjadi peningkatan pengetahuan kader tentang deteksi dini komplikasi masa nifas dari $23 \%$ yang berpengetahuan baik meningkat menjadi $60 \%$ setelah dilakukan kegiatan pengabdian masyakat.

Kesimpulan: Terjadi peningkatan pengetahuan kader setelah diberikan penyuluhan deteksi dini komplikasi masa nifas melalui buku saku

\section{Keywords:}

cadre empowerment; early detection; postpartum period

\section{ABSTRACT}

Background: The issue of midwifery in the community is a complex issue and needs some attention. Health cadres as the right target in implementing health programs are considered as the first referral point for health services. They are trained and serve as monitors, reminders and supporters to promote bealth.

Method: Increasing cadres' knowledge was carried out through counseling by providing pocket books to a target of 30 people. Knowledge is measured by using questionnaires. This community service was carried out in May 2019 in Penyengat Olak. Village, Jambi Luar Kota sub-district in Muaro Jambi regency.

Results: There was an increase in cadres' knowledge on early detection of postpartum complications from $23 \%$ with good knowledge to $60 \%$ after community service activities were carried out.

Conclusion: There was an increase of the cadre knowledge after given education on early detection of postpartum complication trough pocket books 


\section{PENDAHULUAN}

Masalah kebidanan dimasyarakat merupakan masalah yang kompleks dan perlu peningkatan yang lebih serius. Pemberian layanan kesehatan yang terintegrasi dan mudah diakses, dilakukan oleh klinisi yang bertanggung jawab untuk memenuhi sebagian besar kebutuhan layanan kesehatan personal, membina kemitraan yang berkesinambungan dengan pasien dan praktik dalam konteks keluarga dan komunitas merupakan salah satu upaya untuk mengurangi masalah kebidanan dimasyarakat yaitu kematian maternal dan neonatal.

Komplikasi pada proses kehamilan, persalinan dan nifas juga merupakan salah satu penyebab kematian. Komplikasi kebidanan adalah kesakitan pada ibu hamil, ibu bersalin, ibu nifas, dan atau janin dalam kandungan, baik langsung maupun tidak langsung, termasuk penyakit menular dan tidak menular yang dapat mengancam jiwa ibu dan atau janin. Sebagai upaya menurunkan angka kematian ibu dan kematian bayi maka dilakukan pelayanan/penanganan komplikasi kebidanan.

Pelayanan/penanganan komplikasi kebidanan adalah pelayanan kepada ibu hamil, bersalin, atau nifas untuk memberikan perlindungan dan penanganan definitif sesuai standar oleh tenaga kesehatan kompeten pada tingkat pelayanan dasar dan rujukan (Kemenkes, 2016:116).

Lima penyebab kematian ibu terbesar yaitu perdarahan, hipertensi dalam kehamilan (HDK), infeksi, partus lama/macet dan abortus. Kematian ibu di Indonesia masih didominasi oleh tiga penyebab utama kematian yaitu perdarahan, hipertensi dalam kehamilan (HDK), dan infeksi. Namun proporsinya telah berubah, dimana perdarahan dan infeksi cenderung mengalami penurunan sedangkan HDK proporsinya semakin meningkat. Lebih dari 25\% kematian ibu di Indonesia pada tahun 2013 disebabkan oleh HDK (Kemenkes, 2016:118).

Jika ditinjau dari penyebab kematian ibu terbanyak adalah perdarahan, infeksi maka sangat tepat jika para tenaga kesehatan memberikan perhatian yang sangat tinggi pada masa ini. Adanya masalah pada ibu akan berimbas juga pada kesejahteraan bayi yang diharapkan karena bayi tersebut tidak akan mendapatkan perawatan maksimal dari ibunya (Sulistyawati, 2009)

Masa nifas merupakan masa yang diawali sejak beberapa jam setelah plasenta lahir dan berakhir setelah 6 minggu setelah melahirkan. Akan tetapi seluruh organ kandungan baru pulih kembali, seperti dalam keadaan sebelum hamil dalam waktu 3 bulan setelah bersalin.

Masa nifas tidak kalah penting dengan masa-masa ketika hamil, karena pada saat ini organ-organ reproduksi sedang mengalami proses pemulihan setelah terjadinya proses kehamilan dan bersalin.

Masa nifas dapat dibagi menjadi 3 bagian yaitu pasca nifas, masa nifas dini, dan masa nifas lanjut, yang masing-masing memiliki ciri khas tertentu. Pasca nifas adalah masa setelah persalinan sampai 24 jam sesudahnya (0-24 jam setelah melahirkan). Masa nifas dini adalah masa permulaan nifas yaitu 1 hari sesudah melahirkan sampai 7 hari lamanya (1 minggu pertama). Masa nifas lanjut adalah 1 minggu sesudah melahirkan sampai dengan 6 minggu setelah melahirkan.

Periode pasca persalinan meliputi masa transisi kritis bagi ibu, bayi dan keluarganya secara fisiologis, emosional dan social. Baik di Negara maju maupun Negara berkembang, perhatian utama bagi ibu dan bayi terlalu banyak tertuju pada masa kehamilan dan persalinan, sementara keadaan yang sebenarnya justru merupakan kebalikannya, oleh karena resiko kesakitan dan kematian ibu serta bayi lebih sering terjadi pada masa pascapersalinan. Keadaan ini terutama disebabkan oleh konsekuensi ekonomi, disamping ketidaktersediaan pelayanan atau rendahnya peranan pasilitas kesehatan dalm menyediakan pelayanan kesehatan yang cukup berkualitas. Rendahnya kualitas pelayanan kesehatan juga menyebabkan rendahnya keberhasilan promosi kesehatan dan deteksi dini sera penatalaksanaan yang adekuat terhadap masalah dan penyakit yang timbul pada masa pascapersalinan (Saifuddin, 2008).

Walaupun menderita nyeri dan tidak nyaman, kelahiran bayi biasanya merupakan peristiwa yang menyenangkan karena dengan berakhirnya masa kehamilan yang telah lama 
ditunggu-tunggu dan dimulainya suatu kehidupan baru. Namun kelahiran bayi juga merupakan suatu masa kritis bagi kesehatan ibu. Kemungkinan timbul masalah atau penyulit

Survei Demografi Kesehatan Indonesia (SDKI) 2012, menunjukkan bahwa Angka Kematian Ibu (AKI) di Indonesia adalah 359 per 100.000 kelahiran hidup. Angka ini lebih besar dibanding pencapaian tahun 2007 yaitu 228 per 100.000 kelahiran hidup. Indikator Angka Kematian Bayi (AKB) hanya turun sedikit dari pencapaian tahun 2007, yaitu dari 34 per 1.000 kelahiran hidup menjadi 32 per 1.000 kelahiran hidup. Indikator Angka Kematian Balita (AKABA) dalam SDKI 2012 baru turun menjadi 40 per 1.000 kelahiran hidup (Profil Kesehatan Indonesia, 2016:105)

Pelayanan kesehatan ibu nifas adalah pelayanan kesehatan pada ibu nifas sesuai standar, yang dilakukan sekurang-kurangnya tiga kali sesuai jadwal yang dianjurkan, yaitu pada enam jam sampai dengan tiga hari pasca persalinan, pada hari ke empat sampai dengan hari ke-28 pasca persalinan, dan pada hari ke29 sampai dengan hari ke-42 pasca persalinan.Masa nifas dimulai dari enam jam sampai dengan 42 hari pasca persalinan. Cakupan kunjungan nifas (KF3) di Indonesia dalam kurun waktu delapan tahun terakhir secara umum mengalami kenaikan. Capaian indikator KF3 yang meningkat dalam delapan tahun terakhir merupakan hasil dari berbagai upaya yang dilakukan oleh Pemerintah dan masyarakat termasuk sektor swasta. Provinsi Kepulauan Riau memiliki capaian tertinggi diikuti oleh DI Yogyakarta sebesar 98,49\%, dan Jawa Barat sebesar 97,23\%. Sedangkan provinsi dengan cakupan kunjungan nifas terendah yaitu Papua sebesar 28,34\%, diikuti oleh Papua Barat sebesar 28,5\%, dan Maluku sebesar 43,39\% (Kemenkes, 2016:116).

Sementara itu Provinsi Jambi dengan cakupan kunjungan ibu nifas yaitu 90,86\% telah mencapai target kunjungan ibu nifas provinsi jambi yaitu 90\%. Hasil capaian kunjungan ibu nifas tertinggi adalah Kabupaten Tanjab Timur dengan capaian sebesar 96,14\% jauh melampaui target Provinsi, diikuti kabupaten Sarolangun $94,47 \%$. Kabupaten dengan cakupan terendah adalah Kabupaten Merangin 79,51\% (Dinas Kesehatan Provinsi Jambi,2015:79).

Kader kesehatan adalah warga masyarakat setempat yang dipilih dan ditinjau oleh masyarakat dan dapat bekerja secara sukarela mengelola posyandu (Zulkifli, 2003). Kader kesehatan yang berada dimasyarakat wajib mempunyai bekal tingkat pengetahuan yang tinggi terhadap pengetahuan yang tinggi terhadap kesehatan yang terjadi dikalangan masyarakat. Kader kesehatan merupakan sasaran yang tepat dalam pelaksanaan program kesehatan karena dianggap sebagai tempat rujukan pertama pelayanan kesehatan. Kader kesehatan dilatih dan berfungsi sebagai monitor, pengingat dan pendukung untuk mempromosikan kesehatan (Wang et al, 2012). Kader ini adalah perpanjangan tangan dari puskesmas atau Dinas Kesehatan kepada masyarakat di wilayah kerjanya. Kader dianggap sebagai rujukan dalam penanganan berbagai masalah kesehatan (Trisnawati et al, 2008)

Tugas dari kader kesehatan masyarakat adalah sebagai pemberi informasi dan pelaku penyuluhan kepada masyarakat tentang informasi masalah kesehatan. Kader kesehatan harus mempunyai bekal pengetahuan dan keterampilan untuk menyampaikan informasi dalam penyuluhan (Sulastyawati et al, 2007).

\section{HASIL DAN PEMBAHASAN}

Kegiatan pengabdian masyarakat dilaksanakan pada hari selasa tanggal 4 Mei 2019 pukul 10.00 WIB Kegiatan dilaksanakan di Puskesmas Desa Penyengat Olak. Sasaran terdiri dari seluruh kader sebanyak 30 orang. Kegiatan penyuluhan diberikan dengan metode ceramah, diskusi dan tanya jawab dengan menggunakan media LCD, laptop dan buku saku.

Materi penyuluhan yang diberikan antara lain yaitu pengertian masa nifas, Komplikasi apa saja dalam masa nifas, tujuan Deteksi masa nifas, bagaimana cara pencegahan komplikasi pada masa nifas, bagaimana cara penanganan komplikasi masa nifas, jadwal Kunjungan rumah pada ibu masa nifas. 
Hasil evaluasi pengetahuan (pre dan post test) kader diketahui sebagian besar tingkat pengetahuan kader sebelum kegiatan kurang baik 23 orang $(77 \%)$ dan yang baik hanya $7(23 \%)$ orang dan sesudah kegiatan memiliki tingkat pengetahuan baik meningkat menjadi 18 orang $(60 \%)$ dan yang kurang baik berkurang menjadi 12 orang ( 40\%). Hal ini dapat dilihat pada diagram berikut ini:

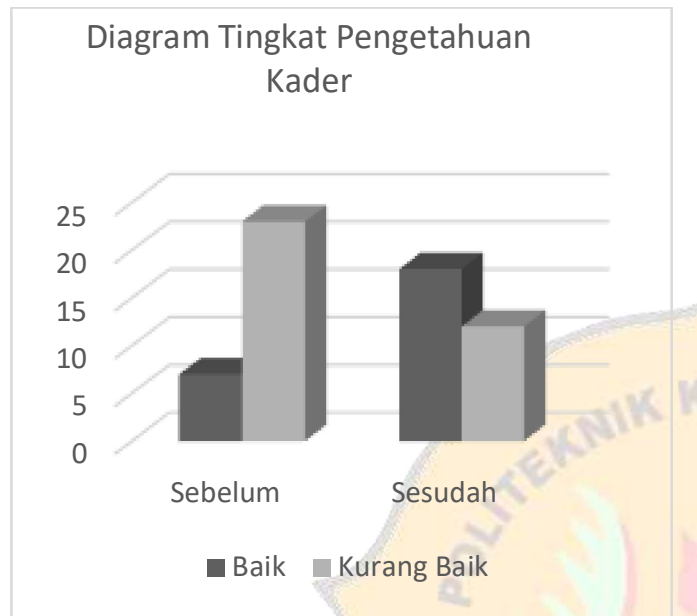

\section{Gambar 1. Tingkat Pengetahuan Kader Sebelum dan Sesudah Kegiatan}

Pelayanan kesehatan ibu nifas adalah pelayanan kesehatan pada ibu nifas sesuai standar, yang dilakukan sekurang-kurangnya tiga kali sesuai jadwal yang dianjurkan, yaitu pada enam jam sampai dengan tiga hari pasca persalinan, pada hari ke empat sampai dengan hari ke-28 pasca persalinan, dan pada hari ke29 sampai dengan hari ke-42 pasca persalinan. Masa nifas dimulai dari enam jam sampai dengan 42 hari pasca persalinan. Kader kesehatan adalah warga masyarakat setempat yang dipilih dan ditinjau oleh masyarakat dan dapat bekerja secara sukarela mengelola posyandu (Zulkifli, 2003). Kader kesehatan yang berada dimasyarakat wajib mempunyai bekal tingkat pengetahuan yang tinggi terhadap pengetahuan yang tinggi terhadap kesehatan yang terjadi dikalangan masyarakat. Kader kesehatan merupakan sasaran yang tepat dalam pelaksanaan program kesehatan karena dianggap sebagai tempat rujukan pertama pelayanan kesehatan. Kader kesehatan dilatih dan berfungsi sebagai monitor, pengingat dan pendukung untuk mempromosikan kesehatan (Wang et al., 2012 cit. Asutik dan Palupi 2019 ). Kader ini adalah perpanjangan tangan dari puskesmas atau Dinas Kesehatan kepada masyarakat di wilayah kerjanya. Kader dianggap sebagai rujukan dalam penanganan berbagai masalah kesehatan (Astutik dan Palupi, 2019)

Tugas dari kader kesehatan masyarakat adalah sebagai pemberi informasi dan pelaku penyuluhan kepada masyarakat tentang informasi masalah kesehatan. Kader kesehatan harus mempunyai bekal pengetahuan dan keterampilan untuk menyampaikan informasi dalam penyuluhan (Sulastyawati et al, 2007).

Berdasarkan hasil pengabdian masyarakat sebelum dilakukan penyuluhan diketahui bahwa Sebagian besar kader memiliki pengetahuan kurang baik tentang deteksi dini komplikasi masa nifas.

Hal ini juga sesuai dengan hasil penelitian yang dilakukan oleh Palupi (2013), yang menyatakan bahwa setelah dilakukan penyuluhan dengan buku saku tingkat pengetahuan kader tentang tanda bahaya kehamilan dalam kategori baik.

\section{KESIMPULAN}

Kegiatan pengabdian masyarakat ini telah dilaksanakan dengan baik dan lancar di Desa Penyengat Olak Kec Jambi Luar Kota. Kegiatan pengabdian masyarakat dengan media buku saku diketahui dapat meningkatkan pengetahuan kader tentang deteksi dini komplikasi masa nifas.

\section{DAFTAR PUSTAKA}

Astutik, R.Y, Palupi, M (2019) Modul Pelatihan Program KUWAT: Pda Wanita Menopause Oleh Kader Posyandu, books.google.com

Cunningham, dkk. (1995), Obstetri Williams. Ed. 18 EGC, Jakarta

Kemenkes RI (2016). Profil Kesehatan Indonesia. Kemenkes RI, 2016

Meilani, N (2009) Kebidanan Komunitas, Fitramaya. Yogyakarta

Mochtar, R. (1998). Sinopsis Obstetri, Ed. 1 \& 2 EGC. Jakarta 
Palupi, FH, dkk (2013). Tingkat Pengetahuan Kader Kesehatan tentang Tanda Bahaya Kehamilan di Desa Bolon Kecamatan Colomadu. Jurnal Kesmadaska. Hal. 42-46

Saifuddin, BA. (2008). Acuan Nasional Pelayanan Kesehatan Maternal Neonatal. YBP-SP. Jakarta

Saifuddin, BA. (2002). Panduan Praktis Pelayanan Kesehatan Maternal \& Neonatal. YBP-SP. Jakarta

Sulistyawati, A (2009). Buku Ajar Asuban Kebidanan Nifas. Salemba Medika. Yogyakarta

Varney, H dkk. (2008). Buku Ajar Asuhan Kebidanan. Ed. 4 volume 2 EGC. Jakarta

Wiknjosastro, H. (2007). Ilmu Kebidanan. YBP-SP. Jakarta

Zulkifli, (2003) Posyandu dan Kader Kesehatan. Depkes RI. Jakarta

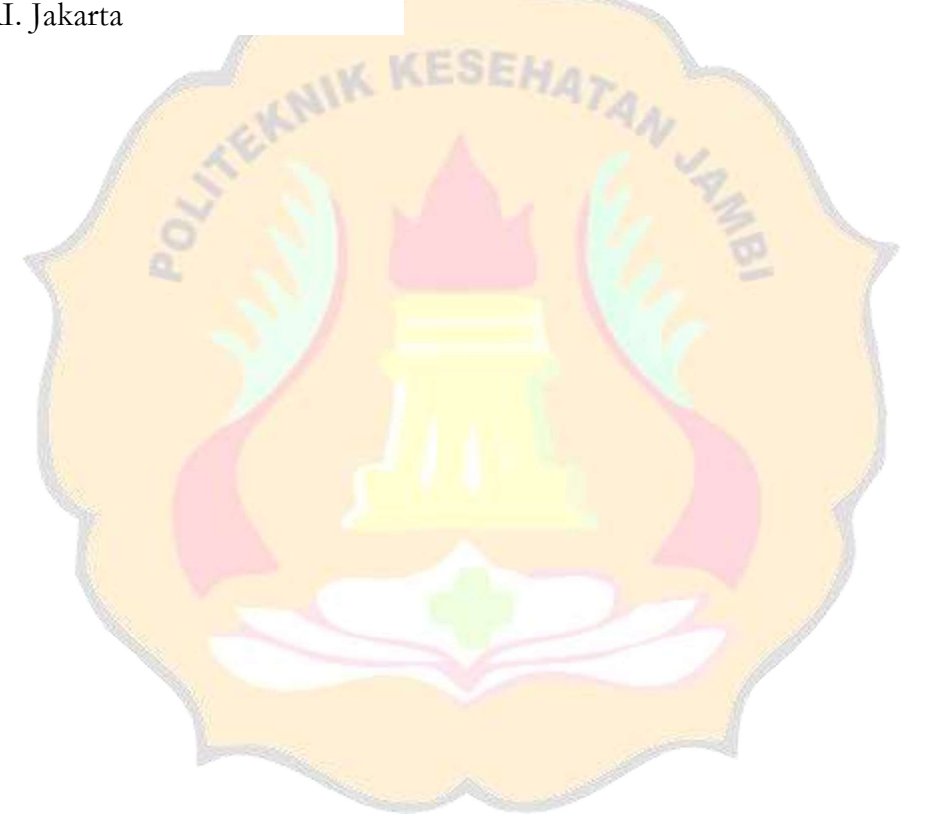

